\title{
Research on the Conversational Repair of Learners of Chinese as a Second Language in Oral Classroom
}

\author{
Mengyao Liu ${ }^{1, a}$ and Tianyu Wang ${ }^{2, b^{*}}$ \\ ${ }^{1}$ Chinese Language and Culture College, Yunnan Normal University, Kunming, Yunnan, 650500, \\ China \\ ${ }^{2}$ Chinese Language and Culture College, Yunnan Normal University, Kunming, Yunnan, 650500, \\ China \\ a1462997952@qq.com, bwangtianyu18@126.com \\ * The corresponding author
}

Keywords: Conversational repair; Learners of Chinese as a second language; Oral classroom

\begin{abstract}
In this paper, the conversational repair of learners of Chinese as a second language in oral classroom is taken as the research content to analyze the changes of students' conversational repair method and repair content at different learning stages. From the repair method, with the improvement of students' learning level and the awareness of self language monitoring, the proportion of other-initiation in students' conversational repair has gradually declined, and the proportion of self-initiation is increasing gradually. With the increase of the difficulty of trouble source, the proportion of other-repair gradually increases, and the change of self-repair is not large. From the analysis of repair content, with the improvement of students' learning level, the proportion of grammatical repair decreases, and the proportion of vocabulary and pronunciation repair gradually increases.
\end{abstract}

\section{Introduction}

Conversational repair is a branch of conversation analysis in sociolinguistics. It was first proposed by American social linguist Emanuel Schegloff et al in 1977. "Conversational repair" refers to the phenomenon that the two sides of the communication restate all aspects of the possible problem and correct the wrong content in the process of conversation. In terms of initiation and repair methods, the conversational repair can be divided into four types: self-initiation self-repair, self-initiation other-repair, other-initiation other-repair and other-initiation self-repair. With the continuous development of the teaching of Chinese as a foreign language, the conversational repair has been applied to the study of Chinese second language learners. By analyzing the relationship between the type of revision and the content of the amendment, we can clearly see the factors that affect the quality of oral output. By analyzing the relationship between the type of conversational repair and the repair content, we can clearly see the factors that affect the quality of students' oral output.

\section{Survey on Classroom Conversational Repair of Learners of Chinese as a Second Language}

Survey Design. In order to understand the characteristics of the conversational repair of learners of Chinese as a second language in the oral classroom at different stages, the author adopted the method of classroom observation to enter the primary, intermediate and advanced oral classrooms to preliminarily record the conversation fragments with the students' conversational repair phenomenon and then rewrite and analyze them.

Survey Objects. The survey objects were Chinese learners of primary oral class, intermediate oral class, advanced audio-visual class in Yunnan Normal University.

Survey Methods. The classroom observation method was used to record the conversational repair phenomenon of learners in Chinese oral classroom. The record content included the conversational repair type, conversational repair content (pronunciation, grammar, and vocabulary). The method of the combination of quantitative analysis and qualitative analysis was used to analyze 
the characteristics of students' conversational repair at different stages.

Survey Implementation. The author listened to 10 class hours( 45 minutes per class hour) of the primary oral class, the intermediate oral class and the advanced audio-visual class respectively, and collected 123 effective students' conversational repair phenomena in primary class, 106 in intermediate class and 58 in advanced class. For some representative conversational fragments, the transliteration symbols provided in Wangqi Jiang's "Contemporary Pragmatics" were used to transcribe.

Survey Results. Changes of students' conversational repair types at different stages. In the primary stage, the proportion of other-initiation self-repair is the largest in students' conversational repair, followed by other-initiation other-repair, and then the self-initiation self-repair, and finally the self-initiation other-repair. In the intermediate stage, the proportion of self-initiation self-repair is the largest, followed by other-initiation self-repair, and then the other-initiation other-repair, and finally the self-initiation other-repair. In the advanced stage, the proportion of self-initiation other-repair and other-initiation self-repair is the largest, followed by the self-initiation self-repair, and finally the other-initiation other-repair.

Changes of students' conversational repair content at different stages. In the primary stage, grammar is repaired the most, followed by vocabulary, and finally the pronunciation. In the intermediate stage, vocabulary is repaired the most, followed by grammar, and finally the pronunciation. In the advanced stage, vocabulary is repaired the most, followed by the pronunciation, and finally the grammar.

\section{Comparative Analysis of Students' Conversational Repair in Oral English at Different Learning Stages}

\section{Comparison of Students' Conversational Repair Types at Various Stages}

Table 1 The proportion of students' conversational repair types at each stage

\begin{tabular}{|c|c|c|c|c|c|c|c|c|c|c|c|c|}
\hline & \multicolumn{4}{|c|}{ Primary stage } & \multicolumn{4}{c|}{ Intermediate stage } & \multicolumn{3}{c|}{ Advanced stage } \\
\hline $\begin{array}{c}\text { Repai } \\
\text { r } \\
\text { types }\end{array}$ & $\begin{array}{c}\text { Self-i } \\
\text { nitiati } \\
\text { on } \\
\text { other } \\
\text { repai } \\
\text { r }\end{array}$ & $\begin{array}{c}\text { Self-in } \\
\text { itiation } \\
\text { self-re } \\
\text { pair }\end{array}$ & $\begin{array}{c}\text { Other-i } \\
\text { nitiatio } \\
\text { n } \\
\text { other-r } \\
\text { epair }\end{array}$ & $\begin{array}{c}\text { Other- } \\
\text { initiati } \\
\text { on } \\
\text { self-re } \\
\text { pair }\end{array}$ & $\begin{array}{c}\text { Self-i } \\
\text { nitiati } \\
\text { on } \\
\text { other- } \\
\text { repair }\end{array}$ & $\begin{array}{c}\text { Self-in } \\
\text { itiation } \\
\text { self-re } \\
\text { pair }\end{array}$ & $\begin{array}{c}\text { Other- } \\
\text { initiati } \\
\text { on } \\
\text { other- } \\
\text { repair }\end{array}$ & $\begin{array}{c}\text { Other- } \\
\text { initiati } \\
\text { on } \\
\text { self-re } \\
\text { pair }\end{array}$ & $\begin{array}{c}\text { Self- } \\
\text { initia } \\
\text { tion } \\
\text { other } \\
\text {-repa } \\
\text { ir }\end{array}$ & $\begin{array}{c}\text { Self-i } \\
\text { nitiati } \\
\text { on } \\
\text { self-r } \\
\text { epair }\end{array}$ & $\begin{array}{c}\text { Other- } \\
\text { initiati } \\
\text { on } \\
\text { other- } \\
\text { repair }\end{array}$ & $\begin{array}{c}\text { Other } \\
\text {-initia } \\
\text { tion } \\
\text { self-r } \\
\text { epair }\end{array}$ \\
\hline $\begin{array}{c}\text { Numb } \\
\text { er of } \\
\text { times }\end{array}$ & 10 & 32 & 35 & 46 & 20 & 32 & 25 & 29 & 18 & 12 & 10 & 18 \\
\hline $\begin{array}{c}\text { Propo } \\
\text { rtion }\end{array}$ & $8.2 \%$ & $26 \%$ & $28.4 \%$ & $37.4 \%$ & $18.9 \%$ & $30.2 \%$ & $23.6 \%$ & $27.3 \%$ & $31 \%$ & 20.7 & $17.3 \%$ & $31 \%$ \\
\hline
\end{tabular}

As shown in Table 1, in primary oral Chinese class, the proportion of the other-initiation self-repair of students' conversational repair is the largest, and the self-initiation other-repair is the smallest. From the initiation method, the proportion of the other-initiation is much greater than that of self-initiation. From the point of view of repair, the proportion of self-repair is much greater than that of other-repair. It can be seen that the self-repair occupies the advantage.

In the intermediate oral Chinese class, the most frequent type of students' conversational repair is self-initiation self-repair, and the least is self-initiation other-repair. From the initiation method, there is little difference between the self-initiation and other-initiation. From the point of view of repair, the self-repair is more than the other-repair, and the self-repair occupies the advantage.

In the advanced stage, the total number of times of students' conversational repair decreases significantly. In conversational repair at the advanced stage, the most frequent ones are self-initiation other-repair and other-initiation self-repair, accounting for $31 \%$ each, and the least is 
the other-initiation self-repair. From the initiation method, the proportion of self-initiation is the largest. From the repair method, the self-repair has a slight advantage.

Comparison of the Students' Conversational Repair Content in Oral Classroom at Different Stages

Table 2 The proportion of students' conversational repair content at different stages

\begin{tabular}{|c|c|c|c|c|c|c|c|c|c|}
\hline & \multicolumn{3}{|c|}{ Primary } & \multicolumn{3}{c|}{ Intermediate } & \multicolumn{3}{c|}{ Advanced } \\
\hline $\begin{array}{c}\text { Repai } \\
\text { r } \\
\text { conte } \\
\text { nt }\end{array}$ & $\begin{array}{c}\text { Pronun } \\
\text { ciation }\end{array}$ & $\begin{array}{c}\text { Gram } \\
\text { mar }\end{array}$ & $\begin{array}{c}\text { Vocab } \\
\text { ulary }\end{array}$ & $\begin{array}{c}\text { Pronun } \\
\text { ciation }\end{array}$ & $\begin{array}{c}\text { Gram } \\
\text { mar }\end{array}$ & $\begin{array}{c}\text { Vocabu } \\
\text { lary }\end{array}$ & $\begin{array}{c}\text { Pronun } \\
\text { ciation }\end{array}$ & $\begin{array}{c}\text { Gram } \\
\text { mar }\end{array}$ & $\begin{array}{c}\text { Vocab } \\
\text { ulary }\end{array}$ \\
\hline $\begin{array}{c}\text { Num } \\
\text { ber } \\
\text { of } \\
\text { times }\end{array}$ & 35 & 50 & 38 & 27 & 32 & 47 & 23 & 8 & 27 \\
\hline $\begin{array}{c}\text { Prop } \\
\text { ortio } \\
\mathrm{n}\end{array}$ & $28.5 \%$ & $40.7 \%$ & $30.9 \%$ & $25.5 \%$ & $30.2 \%$ & $44.3 \%$ & $39.7 \%$ & $13.8 \%$ & $46.5 \%$ \\
\hline
\end{tabular}

From the data statistics of Table 2, it can be seen that in the primary stage, the proportion of students' conversational repair content from large to small is grammar, vocabulary and pronunciation. In the intermediate stage, the proportion is vocabulary, grammar and pronunciation in turn, and in the advanced stage, the proportion is vocabulary, pronunciation and grammar in turn.

In terms of grammar, the proportion of grammar repair from primary stage to advanced stage declines gradually, especially from intermediate stage to advanced stage, and the proportion declines by $16.4 \%$.

Table 3 The relationship between the number of times of grammar repair in each stage and the four types of repair

\begin{tabular}{|c|c|c|c|c|c|c|c|c|c|c|c|c|}
\hline & \multicolumn{4}{|c|}{ Primary stage } & \multicolumn{3}{c|}{ Intermediate stage } & \multicolumn{3}{c|}{ Advanced stage } \\
\hline $\begin{array}{c}\text { Repai } \\
\text { r } \\
\text { types }\end{array}$ & $\begin{array}{c}\text { Self-i } \\
\text { nitiati } \\
\text { on } \\
\text { other- } \\
\text { repair }\end{array}$ & $\begin{array}{c}\text { Self-i } \\
\text { nitiati } \\
\text { on } \\
\text { self-re } \\
\text { pair }\end{array}$ & $\begin{array}{c}\text { Other } \\
\text {-initia } \\
\text { tion } \\
\text { other- } \\
\text { repair }\end{array}$ & $\begin{array}{c}\text { Othe } \\
\text { r-init } \\
\text { iatio } \\
\text { n } \\
\text { Self- } \\
\text { repai } \\
\text { r }\end{array}$ & $\begin{array}{c}\text { Self-i } \\
\text { nitiati } \\
\text { on } \\
\text { other- } \\
\text { repair }\end{array}$ & $\begin{array}{c}\text { Self-in } \\
\text { itiatio } \\
\text { n } \\
\text { self-re } \\
\text { pair }\end{array}$ & $\begin{array}{c}\text { Other- } \\
\text { initiati } \\
\text { on } \\
\text { other- } \\
\text { repair }\end{array}$ & $\begin{array}{c}\text { Other } \\
\text {-initia } \\
\text { tion } \\
\text { Self-r } \\
\text { epair }\end{array}$ & $\begin{array}{c}\text { Self- } \\
\text { initia } \\
\text { tion } \\
\text { other } \\
\text {-repa } \\
\text { ir }\end{array}$ & $\begin{array}{c}\text { Self-i } \\
\text { nitiati } \\
\text { on } \\
\text { self-r } \\
\text { epair }\end{array}$ & $\begin{array}{c}\text { Other- } \\
\text { initiati } \\
\text { on } \\
\text { other- } \\
\text { repair }\end{array}$ & $\begin{array}{c}\text { Other } \\
\text {-initia } \\
\text { tion } \\
\text { Self-r } \\
\text { epair }\end{array}$ \\
\hline $\begin{array}{c}\text { Num } \\
\text { ber of } \\
\text { times } \\
\text { of } \\
\text { gram } \\
\text { mar } \\
\text { repair }\end{array}$ & 6 & 6 & 13 & 25 & 8 & 9 & 6 & 9 & 2 & 2 & 1 & 3 \\
\hline $\begin{array}{c}\text { Propo } \\
\text { rtion }\end{array}$ & $12 \%$ & $12 \%$ & $26 \%$ & $50 \%$ & $25 \%$ & $28.1 \%$ & $18.8 \%$ & $\begin{array}{c}28.1 \\
\%\end{array}$ & $25 \%$ & $25 \%$ & $12.5 \%$ & 37.5 \\
$\%$
\end{tabular}

As can be seen from Table 3, the proportion of the other-initiation self-repair in the grammar conversational repair in the primary stage is the largest. For the initiation method of the grammar repair in the intermediate stage, there is little difference between other-initiation and self-initiation, however, the self-repair occupies obvious advantage in repair method. In the advanced stage, the proportion of the other-initiation self-repair in 8 grammar repairs is the largest, and the other-initiation other-repair is the least. From the initiation method, the other-initiation is slightly ahead of self-initiation, while the self-repair is prior to other-repair. 
From the pronunciation angle(All the pronunciation repair cases for the vocabulary in this article are judged according to the classroom situation. Students have known the meaning of these words, and all the pronunciation repairs have been distinguished from the vocabulary repair), the proportion of pronunciation repair from the primary stage to the intermediate stage decreases slightly, and increases significantly in the advanced stage.

Table 4 The relationship between the number of times of pronunciation repair in each stage and the four types of repair

\begin{tabular}{|c|c|c|c|c|c|c|c|c|c|c|c|c|}
\hline & \multicolumn{4}{|c|}{ Primary stage } & \multicolumn{4}{|c|}{ Intermediate stage } & \multicolumn{4}{|c|}{ Advanced stage } \\
\hline $\begin{array}{l}\text { Repa } \\
\text { ir } \\
\text { type } \\
\text { s }\end{array}$ & $\begin{array}{c}\text { Self- } \\
\text { initia } \\
\text { tion } \\
\text { other } \\
\text {-repa } \\
\text { ir }\end{array}$ & $\begin{array}{c}\text { Self-i } \\
\text { nitiati } \\
\text { on } \\
\text { self-re } \\
\text { pair }\end{array}$ & $\begin{array}{l}\text { Other- } \\
\text { initiati } \\
\text { on } \\
\text { other-r } \\
\text { epair }\end{array}$ & $\begin{array}{l}\text { Other } \\
\text {-initia } \\
\text { tion } \\
\text { Self-r } \\
\text { epair }\end{array}$ & $\begin{array}{c}\text { Self- } \\
\text { initia } \\
\text { tion } \\
\text { other } \\
\text {-repa } \\
\text { ir }\end{array}$ & $\begin{array}{c}\text { Self-i } \\
\text { nitiat } \\
\text { ion } \\
\text { self-r } \\
\text { epair }\end{array}$ & $\begin{array}{c}\text { Other } \\
\text {-initia } \\
\text { tion } \\
\text { other- } \\
\text { repair }\end{array}$ & $\begin{array}{l}\text { Other } \\
\text {-initia } \\
\text { tion } \\
\text { Self-r } \\
\text { epair }\end{array}$ & $\begin{array}{c}\text { Self-i } \\
\text { nitiati } \\
\text { on } \\
\text { other } \\
\text {-repai } \\
\text { r }\end{array}$ & $\begin{array}{l}\text { Self-i } \\
\text { nitiat } \\
\text { ion } \\
\text { self-r } \\
\text { epair }\end{array}$ & $\begin{array}{c}\text { Other } \\
\text {-initia } \\
\text { tion } \\
\text { other- } \\
\text { repair }\end{array}$ & $\begin{array}{c}\text { Other } \\
\text {-initia } \\
\text { tion } \\
\text { Self-r } \\
\text { epair }\end{array}$ \\
\hline $\begin{array}{c}\text { Num } \\
\text { ber } \\
\text { of } \\
\text { time } \\
\text { s of } \\
\text { pron } \\
\text { unci } \\
\text { ation } \\
\text { repai } \\
\text { r }\end{array}$ & 1 & 10 & 16 & 8 & 2 & 6 & 12 & 7 & 4 & 3 & 12 & 4 \\
\hline $\begin{array}{c}\text { Prop } \\
\text { ortio } \\
n\end{array}$ & $2.9 \%$ & $\begin{array}{c}28.6 \\
\%\end{array}$ & $45.6 \%$ & $\begin{array}{c}22.9 \\
\%\end{array}$ & $7.3 \%$ & $\begin{array}{c}22.3 \\
\%\end{array}$ & $\begin{array}{c}44.5 \\
\%\end{array}$ & $\begin{array}{c}25.9 \\
\%\end{array}$ & $\begin{array}{c}17.3 \\
\%\end{array}$ & $13 \%$ & $\begin{array}{c}52.2 \\
\%\end{array}$ & $\begin{array}{c}17.4 \\
\%\end{array}$ \\
\hline
\end{tabular}

From the data in Table 4, it can be seen that the other-initiation other-repair in pronunciation repair has priority in the primary, intermediate and advanced stages, indicating that it is difficult for students to identify and repair pronunciation errors themselves, and students always need to rely on teachers to correct their pronunciation errors. In particular, the pronunciation problems in the advanced stage is more prominent.

From the perspective of vocabulary, the proportion of vocabulary increases gradually from the primary stage to the intermediate stage to the advanced stage.

Table 5 The relationship between the number of times of vocabulary repair in each stage and the four types of repair

\begin{tabular}{|c|c|c|c|c|c|c|c|c|c|c|c|c|}
\hline & \multicolumn{4}{|c|}{ Primary stage } & \multicolumn{4}{|c|}{ Intermediate stage } & \multicolumn{4}{|c|}{ Advanced stage } \\
\hline Repair types & $\begin{array}{l}\text { Self-initiati } \\
\text { on } \\
\text { other-repair }\end{array}$ & $\begin{array}{l}\text { Self-init } \\
\text { iation } \\
\text { self-repa } \\
\text { ir }\end{array}$ & $\begin{array}{c}\text { Other-init } \\
\text { iation } \\
\text { other-rep } \\
\text { air }\end{array}$ & $\begin{array}{l}\text { Other-init } \\
\text { iation } \\
\text { self-repai } \\
\text { r }\end{array}$ & $\begin{array}{l}\text { Self-initia } \\
\text { tion } \\
\text { other-repa } \\
\text { ir }\end{array}$ & $\begin{array}{c}\text { Self-initi } \\
\text { ation } \\
\text { self-repai } \\
\text { r }\end{array}$ & $\begin{array}{c}\text { Other-init } \\
\text { iation } \\
\text { other-repa } \\
\text { ir }\end{array}$ & $\begin{array}{l}\text { Other-ini } \\
\text { tiation } \\
\text { self-repa } \\
\text { ir }\end{array}$ & $\begin{array}{l}\text { Self-initiation } \\
\text { other-repair }\end{array}$ & $\begin{array}{l}\text { Self-initiation } \\
\text { self-repair }\end{array}$ & $\begin{array}{c}\text { Other-initiation } \\
\text { other-repair }\end{array}$ & $\begin{array}{l}\text { Other-initiation } \\
\text { self-repair }\end{array}$ \\
\hline $\begin{array}{l}\text { Number of } \\
\text { times of } \\
\text { vocabulary } \\
\text { repair }\end{array}$ & 3 & 16 & 6 & 13 & 5 & 19 & 8 & 15 & 12 & 7 & 5 & 3 \\
\hline Proportion & $7.9 \%$ & $\begin{array}{c}42.1 \\
\%\end{array}$ & $15.8 \%$ & $34.2 \%$ & $10.6 \%$ & $40.4 \%$ & $17 \%$ & $32 \%$ & $44.4 \%$ & $25.9 \%$ & $18.6 \%$ & $11.1 \%$ \\
\hline
\end{tabular}

The Main Problems of Conversational Repair and Suggestions for Improvement

Main Problems of Conversational Repair. Through the comparative analysis of the students' conversational repair type and conversational repair content in each stage, the author finds that there 
are the following problems in students' conversational repair:

The first point is that the self-monitoring of language forms is not strong enough. It mainly exists in the primary stage. Students can repair the problems, but need to be based on teacher initiation, and students' self-monitoring consciousness is not strong.

The second point is that the grammar exercises that have been learned are not enough. The proportion of grammar repair in the primary stage is the largest, and most of the repair types of the grammar trouble source are other-initiation self-repair, which indicates that these grammar trouble sources are caused by students' insufficient practice.

The third point is that students are easy to be influenced by the negative transfer of mother tongue in the use of grammar. Due to the incomplete mastery of grammar in the primary stage, students in primary stage are easily influenced by the negative transfer of mother tongue.

The fourth point is that learners have low accuracy in using the vocabulary acquired after class. Students may not completely understand the vocabulary acquired after class, so these words may be transferred to the wrong situations, thus leading to errors in vocabulary use.

The fifth point is that the similar grammar or vocabulary is easily confused. In the intermediate stage, the frequency at which the similar grammar and some synonyms in the intermediate stage Chinese occur increases, which makes students easily confused with grammar rules or words.

The sixth point is that learners are difficult to monitor and correct pronunciation errors. Since grammar is the focus of teachers and students in the primary and intermediate stages, there are relatively few pronunciation repairs, and the problem of pronunciation is highlighted in the advanced stage. Students' pronunciation problems are hard to be monitored or repaired by students themselves.

Suggestions for Improvement. Teachers should attach importance to conversational repair in class, and timely feedback and repair can improve students' learning efficiency. They should choose a appropriate method, and choose the repair method according to the difficult degree of the trouble source. Teachers should pay attention to key points when repairing the trouble source. They should also give an explanation after the repair. After repairing the trouble source, teachers should explain to students why such repair is needed.

Learners should enhance their awareness of language monitoring in their oral output, and constantly adjust their language forms to achieve the effect of matching language knowledge. They should pay attention to the accumulation of vocabulary. In terms of vocabulary acquired from non classroom approaches, especially fixed collocations, students can tend to memorize chunks in order to increase the accuracy of use[10]. Students should pay attention to the standard of their pronunciation. They should focus on practicing the phonemes that are not in the mother tongue in the Chinese language, they can not directly equate the tone of the native language to the Chinese tone, and they should often ask teachers or Chinese friends to correct their pronunciation when necessary. Students should master the strategy of repair. In the classroom and life communication, they should pay attention to the difference of the repair strategies, and should choose the corresponding repair strategies on different occasions.

\section{Conclusions}

Through the investigation and analysis of the repair phenomenon of learners of Chinese as a second language in oral classroom, the language ability of students at various stages has been truly demonstrated. Students' conversational repair is not a simple process of initiation and repair. It also contains internal psychological factors of students and external factors such as the trouble source. Through the analysis of the students' conversational repair, the author realistically understands the oral ability of the three class students, and also truly understands the importance of input and interaction between teachers and students.

\section{References}

[1] Guodong Yu: Conversation Analysis[M], Shanghai: Shanghai Foreign Language Education 
Press, 2008.

[2] Jianqin Wang: Study of Second Language Acquisition[M](2014), Beijing: The Commercial Press, 2009.

[3] Jiayin Liu: Study on the Conversational Repair in Classroom Initiation and repair of Chinese Second Language Learners[J], Journal of Northeast Normal University(Social Philosophy Science Edition), 2016(3).

[4] Jianji Lu: Grammatical Error Analysis of Foreigners Learning Chinese [J], Language Teaching and Linguistic Studies, 1994(1).

[5] Yun Hong: Error Correction Feedback in Second Language Classroom Teaching: A Study from the Perspective of Chaos Theory[M], Beijing, Minzu University of China Press, 2011.

[6] Yunjuan Dai: A Study on Conversational Repair of the Chinese Second Language Learners[J], Chinese Language Learning, 2007(6).

[7] Xiaochuan Peng and Yukui Ma: The Understanding and Strategy of the Vocabulary Teaching of Chinese as a Second Language[J], Applied Liguistics, 2010(1).

[8] Xiaomei Zu: The Investigation and Analysis of the Correction Feedback in Chinese Class[J], Chinese Language Learning, 2008(1).

[9] Yongyi Wu and Cheng Wang: A Study on Conversational Repair Strategies in CSL Classroom[J], Journal of East China Normal University(Philosophy and Social Science Edition), 2016(1).

[10] Feng Liu: A Study on the Self Repair of the Spoken Chinese of the Foreign Students[J], Journal of College of Chinese Language and Culture of Jinan University, 2014(1).

[11] Cheng Wang and Yongyi Wu: Study on Conversational Repair Ability of Learners of Chinese as the Second Language[J], Journal of College of Chinese Language and Culture of Jinan University, 2017(4).

[12] Schegloff,E.A.,G.Jefferson and H.Sacks.The preference for Self-repair in the organization of repair in conversation[J].Language, 1977.

[13] Kasper,G.Repair in foreign language teaching studies[J].Second Language Acquisition,1985.

[14] McHoul,A.W.Theorganization of repair in class room talk[J].Language in Society,1990. 